\title{
Low vitamin $C$ intake increases risk of pre-eclampsia in high pesticide exposure area
}

\author{
Rifatul Masrikhiyah*, Suhartono**, and Martha Irene Kartasurya***
}

\begin{abstract}
*Department of Nutrition,

Faculty of Medicine,

Diponegoro University, Semarang

**Department of Environmental

Health, Faculty of Public Health

Diponegoro University, Semarang

***Department of Public Health

Nutrition, Faculty of Public Health

Diponegoro University, Semarang

\section{Correspondence:}

Rifatul Masrikhiyah

Department of Nutrition,

Faculty of Medicine,

Diponegoro University, Semarang

Email:

rifatul.masrikhiyah@yahoo.com

\section{BACKGROUND}

Pre-eclampsia is the largest direct cause (42\%) of maternal mortality death in Brebes district in 2013. The cause of pre-eclampsia is not known with certainty, oxidative stress being one of its causes. The aim of this study was to determine macro- and micronutrient intakes that do not correspond to the needs, as pre-eclampsia risk factors in post-partum women.

\section{METHODS}

The research was an observational study of case control design. Study subjects were 20-35 year-old post partum women consisting of 55 cases (pre-eclampsia) and 55 controls (non-pre-eclampsia). Nutrient intakes were measured using semi-quantitative food frequency questionnaires and data on levels of pesticide exposure, body mass index (BMI), midupper arm circumference (MUAC) and education were collected from structured interviews. Data was analyzed by chi-square tests and multiple logistic regression.
\end{abstract}

Univ Med 2016;35:128-34

DOI: 10.18051/UnivMed.2016.v35.128-134

pISSN: 1907-3062 / eISSN: 2407-2230

This open access article is distributed under a Creative Commons Attribution-Non Commercial-Share Alike 4.0 International License

\section{RESULTS}

There was no difference in age and MUAC between the cases and controls. Low vitamin C intake (OR: 20.93; 95\% CI: 2.72 - 161.36), high polyunsaturated fatty acid intake (OR: $10.50 ; 95 \%$ CI: $2.47-44.57)$, and low vitamin E intake (OR: 8.57 ; 95\% CI: 2.07 - 35.46) were pre-eclampsia risk factors after controled for pesticide exposure, BMI and education. Low vitamin $\mathrm{C}$ intake played the most important role in the incidence of preeclampsia.

\section{CONCLUSION}

Low vitamin $\mathrm{C}$ intake played the most important role toward preeclampsia. Greater caution is needed when issuing recommendations regarding the consumption of vitamin supplements in pregnancy, as high doses of some vitamins may be deleterious.

Keywords: Pre-eclampsia, vitamin C, vitamin E, polyunsturated fatty acids, pesticide exposure 


\section{INTRODUCTION}

Pre-eclampsia still constitutes a pubic health problem in developed and developing countries, contributing toward global maternal and perinatal morbidity and mortality. ${ }^{(1)}$ Pre-eclampsia affects $5-10 \%$ of all global pregnancies. The prevalence of pre-eclampsia in developing countries reaches $16.7 \%$ and around $40-60 \%$ is estimated to contribute toward maternal mortality in developing countries. ${ }^{(2)}$ The World Health Organization estimates that the incidence of preeclampsia is seven-fold higher in developing countries ( $2.8 \%$ of live births) than in developed countries $(0.4 \%)$. ${ }^{(3)}$

According to the Health Service of Brebes district, in 2012 the direct causes of the maternal mortality rate (MMR) in this district were hemorrhage $22 \%$, pre-eclampsia $42 \%$, infection $8 \%$, heart failure $14 \%$, dyspnea $4 \%$, ruptured ectopic pregnancy $2 \%$, ectopic pregnancy $2 \%$, post curettage $2 \%$ and others $4 \% .{ }^{(4)}$ Oxidative stress results from an imbalance between free radical production and the antioxidant defense system ${ }^{(5)}$ and is one of the causes of preeclampsia. Nutrients may influence oxidative stress by increasing free radicals/decreasing antioxidants/providing substrates for the formation of free radicals.

A case-control study on 453 pregnant women (151 cases and 302 controls) showed that women with mid-upper arm circumference (MUAC) of $\geq 25.6 \mathrm{~cm}$ had two and a half times greater risk for pre-eclampsia than pregnant women with MUAC of $<25.6 \mathrm{~cm} .{ }^{(6)}$ According to a study conducted by Kartasurya ${ }^{(7)}$ on 200 pregnant/post partum women (50 pre-eclampsia cases and 150 controls), in women with pre-pregnancy body mass index (BMI) scores of $>23 \mathrm{~kg} / \mathrm{m}^{2}$, the risk of pre-eclampsia was four and a half times greater than in women with pre-pregnancy BMI scores of $<23 \mathrm{~kg} / \mathrm{m}^{2}$.

Lipids are involved in the generation of free radicals and polyunsaturated fatty acids (PUFA) tend to be oxidized by free radicals and reactive oxygen species (ROS). A high PUFA intake may render the organism more susceptible to lipid peroxidation, which is strongly suspected to play a important role in the causation of maternal endothelial dysfunction and the appearance of clinical symptoms of pre-eclampsia. ${ }^{(8-10)}$ According to the study by Clausen et al. ${ }^{(11)}$ an increased intake of PUFA in pregnant women increases the risk of pre-eclampsia.

Antioxidants may decrease the level of lipid peroxides by limiting or inactivating their formation. Free radicals may be treated by administration of antioxidants such as vitamins A, C and E. Low intakes of vitamins A, C and E may cause an imbalance between free radicals and antioxidants in the body. A previous study found that low intakes of vitamins A, C and E may increase the risk of pre-eclampsia. ${ }^{(12)}$

Since protein status affects glutathione concentrations, a low protein intake contributes toward oxidative stress, as a result of low glutathione concentrations. Low glutathione concentrations affect the antioxidant effects of glutathione itself, causing free radicals to become uncontrolled, thus resulting in oxidative stress. The results of a study in pregnant women with pre-eclampsia showed that the glutathione concentrations in their blood were lower than in normal pregnant women. ${ }^{(13)}$

A total of 104 pregnant women with preeclampsia and of 206 pregnant women at high risk of, but not suffering from, pre-eclampsia, were studied in second trimester pregnancies. This study showed that there was no relationship between nutritional intake and the development of pre-eclampsia (or other effects) when evaluated for 7 days. ${ }^{(14)}$ A review and bivariate meta-analysis of 36 studies involving 1,699,073 pregnant women showed BMI to be a weak predictor of preeclampsia. $^{(15)}$

Brebes district in Central Java is one of the largest producers of shallots (bawang merah) in Indonesia, and has a high pesticide utilization. Pesticide exposure may cause health disorders in pregnant women. The study conducted by Saldana 
et al. ${ }^{(16)}$ found that pesticide exposure is a risk factor of pre-eclampsia. Based on these facts the present study aimed to determine the macro- and micronutrient intakes that do not correspond to needs, as risk factors of pre-eclampsia in postpartum women residing in areas of high pesticide exposure.

The present study differs from previous studies in the location/site of the study, since it was conducted in Brebes district in an area of high pesticide exposure, where no previous studies had been conducted on the intakes of lipids, proteins and antioxidants (vitamins A, C and E) in relation to pre-eclampsia.

\section{METHODS}

\section{Research design}

This study was of observational case control design and was conducted from February - March 2016 at 3 puskesmas (public health centers) in Brebes district, Central Java, i.e. puskesmas Brebes, Wanasari and Bulakamba.

\section{Research subjects}

The subjects in this study were women of productive age (20-35 years) who were up to 3 months post partum. The number of subjects in this study was 110 , consisting of 55 cases and 55 controls. This number was obtained based on total sampling in the three puskesmas (Brebes, Wanasari and Bulakamba), where 55 subjects were found for the group of cases and 55 subjects for the group of controls. The inclusion criteria were women of productive age (20-35 years), agreeing to participate in the study, being 3 months post partum and diagnosed as having had preeclampsia in pregnancy (as cases), normal pregnant women (as controls), and residing in the catchment area of Bulakamba, Wanasari and Brebes subdistricts, Brebes district. The exclusion criteria for the subjects in this study were women with twin pregnancies and with diabetes mellitus. Pre-eclampsia was diagnosed by health personnel by the criteria of a blood pressure of $\geq 140 / 90$ $\mathrm{mmHg}$ after 20 weeks of pregnancy and of proteinuria.

\section{Anthropometric measurements}

Measurement of BMI and MUAC of the women before pregnancy was performed by health personnel. The BMI of women before pregnancy was obtained from pre-pregnancy body weight divided by height, while MUAC was measured at the start of pregnancy.

\section{Nutrient intake measurements}

Nutrient intakes were obtained from interviews conducted by the investigators using the semi-quantitative food frequency questionnaire. The assessed nutrient intakes comprised total lipids, PUFA, and vitamins A, C and $\mathrm{E}$. The nutrient adequacy level was calculated using the Nutrisurvey 2007 program and based on the Indonesian Recommended Dietary Allowances (IRDA) of 2013. The cut-off point for low protein intake was categorized at $<80 \%$ of IRDA and for adequate protein intake at $\geq 80 \%$ of IRDA. ${ }^{(17)}$ Low intake of vitamins A, C and E was categorized at $<77 \%$ of IRDA and adequate intake at $>77 \%$ of IRDA. ${ }^{(18)}$ The intakes of PUFA and total lipids were categorized as high at $>110 \%$ of IRDA and adequate at $\leq 110 \%$ of IRDA. ${ }^{(17)}$

\section{Exposure to pesticides}

The level of pesticide exposure was obtained through structured interviews, using a list of questions for the interviews and forms for willingness to participate in the study. The level of pesticide exposure was divided into two categories, i.e. mild and severe, with total scores of 1-11 and 12-22, respectively.

\section{Statistical analysis}

Chi square and independent $t$ tests were used to determine differences between cases and controls. Simple logistic regression and multiple logistic regression were used to examine the risk factors of pre-eclampsia. The level of significance used was 0.05 .

\section{Ethical clearance}

This study was conducted after obtaining approval of the ethics commission under no. 051/ EC/FK-RSDK/2016. 
Table 1. Characteristics of study subjects, by cases $(n=55)$ and controls $(n=55)$

\begin{tabular}{lccc}
\hline \multicolumn{1}{c}{ Type } & Cases & Controls & p \\
\hline Age (yrs) & $27.33 \pm 4.98$ & $26.33 \pm 3.94$ & $0.245^{*}$ \\
E ducation (n, & & & \\
Low & $51(92.7)$ & $44(80.0)$ & $0.096^{* *}$ \\
High & $4(7.3)$ & $11(20.0)$ & \\
\hline
\end{tabular}

*independent T-test; ** Chi-square test

\section{RESULTS}

Table 1 shows that with regard to age and level of education of the study subjects, there were no significant differences between cases and controls ( $\mathrm{p}=0.245$ and $\mathrm{p}=0.096$ ).

Table 2 shows the results of the analysis of pre-eclampsia risk factors. The results of simple logistic regression showed that there was a relationship between intakes of nutrients (protein, PUFA, and vitamins A, C and E), BMI, and level of pesticide exposure with the incidence of preeclampsia. Low intake of protein (OR: 5.37; 95\% CI: 1.43 - 20.08), high intake of PUFA (>110\% of IRDA) (OR: 6.55; 95\% CI: $2.62-16.41)$, low intake of vitamin A (OR: 4.84; 95\% CI: 1.28 18.26), low intake of vitamin $C$ (OR: 4.35 ; $95 \%$ CI: 1.33 - 14.24), low intake of vitamin E (OR: 12; $95 \%$ CI: $4.15-34.69$ ), BMI $>23 \mathrm{~kg} / \mathrm{m}^{2}$ (OR: 2.50; 95\% CI: 1.10 - 5.67), severe pesticide exposure (OR: 3.34; 95\% CI: 1.26 - 8.82) are risk factors of the incidence of pre-eclampsia.

The variables that were used as candidates in the multiple logistic regression analysis were those that were significant in the simple logistic regression analysis. These comprised the intakes of protein, PUFA, vitamin A, vitamin C, vitamin $\mathrm{E}$, pesticide exposure, and BMI.

Table 2. Simple logistic regression analysis of risk factors of pre-eclampsia

\begin{tabular}{|c|c|c|c|c|}
\hline Risk factor & Cases $(1, \%)$ & Controls $(n, \%)$ & p & OR $(95 \% \mathrm{CI})$ \\
\hline \multicolumn{5}{|l|}{ Level of protein intake (g) } \\
\hline Low $<80 \%$ of IRDA & $13(23.6)$ & $3(5.5)$ & \multirow[t]{2}{*}{0.015} & 5.37 \\
\hline Adequate $\geq 80 \%$ of IRDA & $42(76.4)$ & $52(945)$ & & $(1.43-20.08)$ \\
\hline \multicolumn{5}{|l|}{ Level of intake of total lipids (g) } \\
\hline High $>110 \%$ of IRDA & $21(38.2)$ & $27(49.1)$ & \multirow[t]{2}{*}{0.346} & 0.64 \\
\hline Adequate $\leq 110 \%$ of IRDA & $34(61.8)$ & $28(509)$ & & $(0.30-1.37)$ \\
\hline \multicolumn{5}{|c|}{$\begin{array}{l}\text { Level of intake of polyunsatur ated fatty } \\
\text { acids (PUFA) (g) }\end{array}$} \\
\hline High $>110 \%$ of IRDA & $47(85.5)$ & $26(473)$ & \multirow[t]{2}{*}{0.001} & 6.55 \\
\hline Adequate $\leq 110 \%$ of IRDA & $8(14.5)$ & $29(52.7)$ & & $(2.62-16.41)$ \\
\hline \multicolumn{5}{|l|}{ Level of vitamin A intake ( $\mathrm{m} \mathrm{cg})$} \\
\hline Low $<77 \%$ of IRDA & $12(21.8)$ & $3(5.5)$ & \multirow[t]{2}{*}{0.026} & 4.84 \\
\hline Adequate $\geq 77 \%$ of IRDA & $43(78.2)$ & $52(945)$ & & $(1.28-18.26)$ \\
\hline \multicolumn{5}{|l|}{ Level of vitamin $\mathrm{C}$ intake ( $\mathrm{m}$ g) } \\
\hline Low $<77 \%$ of IRDA & $14(25.5)$ & $4(7.3)$ & \multirow[t]{2}{*}{0.020} & 4.35 \\
\hline Adequate $\geq 77 \%$ of IRDA & $41(74.5)$ & $51(92.7)$ & & $(1.33-14.24)$ \\
\hline \multicolumn{5}{|l|}{ Level of vitamin $\mathrm{E}$ intake (m g) } \\
\hline Low $<77 \%$ of IRDA & $50(90.9)$ & $25(455)$ & \multirow[t]{3}{*}{0.001} & \multirow{3}{*}{$\begin{array}{c}12.00 \\
(4.15-34.69)\end{array}$} \\
\hline Adequate $\geq 77 \%$ of IRDA & $5(9.1)$ & $30(545)$ & & \\
\hline Body mass index $\left(\mathrm{kg} / \mathrm{m}^{2}\right)$ & & & & \\
\hline$\geq 23.0$ & $24(43.6)$ & $13(236)$ & 0.044 & 2.50 \\
\hline$<230$ & $31(56.4)$ & $42(76.4)$ & & $(1.10-5.67)$ \\
\hline \multicolumn{5}{|l|}{ Level of pesticide exposure } \\
\hline Severe & $18(32.7)$ & $7(12.7)$ & \multirow[t]{2}{*}{0.023} & 3.34 \\
\hline Mild & $37(67.3)$ & $48(873)$ & & $(1.26-8.82)$ \\
\hline
\end{tabular}

IRDA: Indonesian Recommended Dietary Allowances 
Table 3. Multiple logistic regression for risk factors of pre-eclampsia

\begin{tabular}{lccc}
\hline & OR & 95\% C I & p \\
\hline Vitam in C intake & 20.93 & $2.72-161.36$ & 0.001 \\
Polyunsaturated fatty acid intake & 10.50 & $2.47-44.57$ & 0.001 \\
Vitam in E intake & 8.57 & $2.07-35.46$ & 0.003 \\
Pesticide exposure & 5.83 & $1.31-2594$ & 0.021 \\
Vitam in A intake & 8.83 & $0.98-7903$ & 0.052 \\
Prdein intake & 4.93 & $0.97-25.14$ & 0.055 \\
Body mass index & 2.78 & $0.81-9.55$ & 0.105 \\
\hline
\end{tabular}

A low vitamin $\mathrm{C}$ intake was the risk factor with the most important role on the incidence of pre-eclampsia (OR: 20.93; 95\% CI: 2.72161.36). Other risk factors that also played a role on the incidence of pre-eclampsia were high intake of PUFA(OR: 10.50 ; 95\% CI: $2.47-$ 44.57), low vitamin E intake (OR: 8.57; 95\% CI: 2.07 -35.46), and severe pesticide exposure (OR: 5.83; 95\% CI: 1.31 - 25.94) (Table 3).

\section{DISCUSSION}

Low protein intake was a risk factor for the incidence of pre-eclampsia, but was statistically not significant. The results of this study are in agreement with a case control study conducted on 113 women with gestational hypertension and 150 healthy pregnant women in Tehran, that did not show any significant differences in protein intake between the two groups. ${ }^{(19)}$ However, the results of our study differed from those of one study on pregnant or post partum women in Semarang and another study on pregnant women in Makassar, with and without pre-eclampsia, where it was found that low protein intake was a risk factor of preeclampsia in pregnancy. ${ }^{(7,20)}$ Similarly, a study that was conducted in one Indian hospital found that low protein intake was a risk factor of preeclampsia. ${ }^{(21)}$

Low protein intake contributes toward oxidative stress that subseaquently causes preeclampsia. Protein status affects glutathione concentration, where low protein intake leads to low glutathione concentrations. Glutathione is the substrate for the enzyme catalyzing the reduction of ROS and free radicals. Glutathione has an important antioxidant capacity and plays an essential role in the detoxification of endogeneous metabolic products, including lipid peroxides, and of xenobiotic compounds. ${ }^{(22)}$ Low glutathione concentrations increase oxidative stress that causes pre-eclampsia.

High intake of PUFA ( $>110 \%$ of IRDA) is a risk factor of the incidence of pre-eclampsia. This is in line with the study by Clausen et al. ${ }^{(11)}$ who found that high intake of PUFA in pregnant women increased the risk of pre-eclampsia.

Lipids are involved in the generation of free radicals. PUFA in lipid membranes are the main targets of lipid peroxidation by ROS. PUFA are degraded by free radicals, thus producing end products termed malondialdehydes (MDA), which may be used for determining the level of oxidative damage caused by lipid peroxidation. Therefore, high PUFA intake may render the organism more susceptible to lipid peroxidation. Lipid peroxidation is strongly suspected to play an important role in causing endothelial dysfunction and the development of clinical symptoms of pre-eclampsia. ${ }^{(8-10)}$

The results of our study showed that low intakes of vitamin $\mathrm{A}$, vitamin $\mathrm{E}$ and vitamin $\mathrm{C}$ are risk factors for the incidence of preeclampsia. The results of this study agree with those of a study conducted in Yogyakarta, where it was found that pregnant women with a low consumption of vitamins $\mathrm{A}, \mathrm{C}$, and $\mathrm{E}$, and beta carotene were at risk for pre-eclampsia. ${ }^{(12)}$

Vitamins $\mathrm{A}, \mathrm{C}$ and $\mathrm{E}$ act as antioxidants by donating electrons to free radicals for binding to single (unpaired) electrons of free radicals without becoming new free radicals. Free radicals may be treated with the administration 
of antioxidants. An imbalance between free radicals and antioxidants causes oxidative stress. ${ }^{(5)}$ Oxidative stress is considered an important element in the pathogenesis of preeclampsia resulting in endothelial dysfunction and ultimately inducing the syndrome of preeclampsia. $^{(23)}$

The results of our study show that low vitamin $\mathrm{C}$ intake increases the risk of preclampsia. These results are consistent with those of a cohort study conducted on Danish pregnant women, showing that the risk of severe preeclampsia/eclampsia may decrease with increasing vitamin $\mathrm{C}$ intake. ${ }^{(25)}$ However, a review of twenty-nine trials involving 24,300 women who took vitamin $\mathrm{C}$ supplements during pregnancy concluded that vitamin $\mathrm{C}$ supplements do not prevent pregnancy problems, including stillbirth, neonatal mortality, preterm birth, preeclampsia or low birthweight babies. ${ }^{(26)}$ There is no agreement on the optimal gestational time for measurement of vitamin $\mathrm{C}$ intake. However, the second half of pregnancy may reflect vitamin C intake in placental development, since trophoblast invasion is completed by this time. The time of complete placentation is not generally considered to be the most probable gestational time point associated with oxidative stress. ${ }^{(25)}$

In the present study, severe level of pesticide exposure is a risk factor for the incidence of preeclampsia, which agrees with the results of a study in the USA where it was found that women who were exposed to pesticides during pregnancy had a greater risk of pre-eclampsia than did pregnant women who were not exposed to pesticides. ${ }^{(16)}$

Pesticides are one of the sources of free radicals. When free radical production increases and exceeds the capacity of the antioxidant defense system in the body, a condition occurs called oxidative stress. ${ }^{(5)}$ Oxidative stress is considered an important element in the pathogenesis of pre-eclampsia that results in endothelial dysfunction and ultimately causes the syndrome of pre-eclampsia, although its role has not yet been completely analyzed. ${ }^{(23)}$
A limitation of this study was that only nutrient intakes, pesticide exposure and BMI were measured, whereas there are still many other uncontrollable or unavoidable factors that affect pre-eclampsia in pregnant women of productive age, such as immunity, cardiovascular adaptation, and genetic factors. For assessment of nutrient intakes, this study used the semiquantitaive FFQ, which may still contain information bias or recall bias. In this study we did not measure serum NO or MDA concentrations to determine the level of oxidative stress in the women. The public health implications of our findings are that they confirm the current dietary recommendations for intakes of vitamin $\mathrm{A}, \mathrm{C}, \mathrm{E}$ in pregnancy.

\section{CONCLUSIONS}

Low vitamin $\mathrm{C}$ intake plays a most important role toward pre-eclampsia. However, greater caution is also needed in recommending the consumption of vitamin supplements in pregnancy, as high doses of some vitamins may be deleterious.

\section{CONFLICT OF INTERESTS}

There are no conflicts of interest (financial, personal, political, intellectual or religious).

\section{ACKNOWLEDGEMENT}

We thank Kabupaten Brebes Health office staff and heads of Puskesmas Wanasari, Brebes and Bulakamba for facilitating and the research process providing secondary data and the study subjects for their participation.

\section{REFERENCES}

1. National High Blood Pressure Education Program Working Group on High Blood Pressure in Pregnancy. Report of the national high blood pressure education program working group on high blood pressure in pregnancy. Am J Obstet Gynecol 2000;183:S1-22. 
2. Osungbade KO, Ige OK. Public health perspectives of pre-eclampsia in developing countries: implication for health system strengthening. J Pregnancy 2011. Article ID481095, 6 pages. http://dx.doi.org/10.1155/ 2011/481095.

3. Trogstad L, Magnus P, Skjærven R, et al. Previous abortions and risk of pre-eclampsia. Int J Epidemiol 2008;37:1333-40.

4. World Health Organization. Make every mother and child count, in the world health report 2005. Geneva: World Health Organization;2005.

5. Dinas Kesehatan Kabupaten Brebes. Angka kematian ibu (AKI). Laporan Dinas Kesehatan Kabupaten Brebes. Brebes;2013.

6. Powers SK, Jackson MJ. Exercise-induced oxidative stress: cellular mechanisms and impact on muscle force production. J Physiol Rev 2008; 88:1243-12.

7. Endeshaw M, Ambaw F, Aragaw A, et al. Effect of maternal nutrition and dietary habits on preeclampsia: a case-control study. Int J Clin Med 2014;5:1405-16.

8. Kartasurya MI. Pre-eclampsia risk factors of pregnant women in Semarang, Indonesia. IJSBAR 2015;22:31-7.

9. Hung TH, Bruton GJ. Hypoxia and reoxygenation: a possible mechanism for placental oxidative stress in pre-eclampsia. Taiwanese J Obstet Gynecol 2006;43:189-200.

10. Borekci B, Aksoy H, Ozturk N, et al. Correlation between calprotectin and oxidized LDL in preeclampsia. Turkey J Med Sci 2009;39:191-5.

11. Gupta S, Aziz N, Sekhon L, et al. Lipid peroxidation and antioxidant status in preeclampsia : a systematic review. Obstet Gynecol Survey 2009;64:750-9.

12. Clausen T, Slott M, Solvoll K, et al. High intake of energy, sucrose, and polyunsaturated fatty acids is associated with increased risk of preeclampsia. Am J Obstet Gynecol 2001;185:4518.

13. Nofrisa MP, Hartini TNS, Hakimi M. Kurang asupan vitamin A, C, E dan beta karoten meningkatkan kejadian preeklampsia di RSUP dr. Sardjito, Yogyakarta. Gizi Indon 2010;33: 136-42.

14. Rani NA, Naidu JN, Krishnamma. Evaluation of nitric oxide and reduced glutathione levels in pre-eclampsia. IJBRITISH 2014;1:13-7.

15. Al-Ahdab MA. The relationship between dietary intake and pre-eclampsia. J Am Sci 2013;9:185203.
16. Cnossen JS, Leeflang MMG, de Haan EE, et al. Accuracy of body mass index in predicting preeclampsia: bivariate meta-analysis. BJOG 2007;114:1477-85.

17. Saldana TM, Basso O, Baird DD, et al. Pesticide exposure and hypertensive disorders during pregnancy. Environ Health Perspect 2009;117: 1393-6.

18. Hardinsyah. Angka kecukupan energi, protein, lemak dan serat makanan. Prosiding Widyakarya Pangan dan Gizi VIII; 2004 Mei 17-19; Jakarta; 2004.p.323-27.

19. Gibson RS. Principle of nutritional and assessment. 2nd ed. New York: Oxford University Press;2005.

20. Kazemian E, Dorosty-Motlagh AR, Sotoudeh G, et al. Nutritional status of women with gestational hypertension compared with normal pregnant women. Hypertens Pregnancy 2013;32:146-156. DOI: 10.3109/10641955. 2013.784782.

21. Nuryani, Ade AM, Citrakesumasari, et al. Hubungan pola makan, sosial ekonomi, antenatal care dan karakteristik ibu hamil dengan preeklampsia di kota Makassar. Media Gizi Masyarakat Indonesia 2013;2:104-12

22. Bej P, Chhabra P, Sharma AK, et al. Determination of risk factors for pre-eclampsia and eclampsia in a tertiary hospital of India: a case control study. J Family Med Prim Care 2013;2:371-5.

23. Lee DH, Steffes MW, Jacobs DR Jr. Can persistent organic pollutants explain the association between serum gamma glutamyl transferase and type 2 diabetes? Diabetologia 2008;51:402-7.

24. Cindrova-Davies T. Gabor Than award lecture 2008: Pre-eclampsia - from placental oxidative stress to maternal endothelial dysfunction. Placenta 2009;23:55-65.

25. Klemmensen AK, Tabor A, Østerdal ML, et al. Intake of vitamin $\mathrm{C}$ and $\mathrm{E}$ in pregnancy and risk of pre-eclampsia: prospective study among 57,346 women. BJOG 2009;116:964-74.

26. Rumbold A, Ota E, Nagata C, et al. Vitamin C supplementation in pregnancy. Cochrane Database of Systematic Reviews 2015, Issue 9. Art. No.: CD004072. DOI: 10.1002/14651858. CD004072.pub3. 